\title{
Economic Activity Accelerates
}

\begin{abstract}
gainst a background of very stimulative fiscal and monetary actions, economic activity accelerated in the third quarter. Although an inventory adjustment gave the appearance of an economic pause in the first half, underlying demand for goods and services has remained strong throughout 1967. Both consumer and Government expenditures helped maintain final sales at higher-than-average rates of increase during the first half of 1967. The growth of total demand, however, hesitated as business firms sharply reduced outlays for inventories.
\end{abstract}

The pace of the economy in the immediate future will be affected by military developments, the possibility of a tax increase, the final effects of the restoration of the investment tax credit, and work stoppages in the course of labor-management negotiation. In view of the Federal budget situation and the expansive trends in bank credit and money, the prospect of excessive total demand is a major concern.

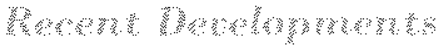

Several important measures of economic activity accelerated during the summer. Employment rose at an 8 per cent annual rate from May to August, more than offsetting declines earlier in the year. Personal income advanced at a 9 per cent annual rate from May to July, compared with a 5 per cent rate earlier this year. Retail sales increased sharply from May to August, bringing the February to August annual rate of growth to 12.5 per cent. Sales of durable goods accounted for much of the recent gains. Industrial production increased from June to July for the first time in seven months, and preliminary data indicate another gain from July to August. All of these figures indicate a revival in total economic activity from the earlier moderate pace.
The economy continued to move forward in early 1967 , but at a somewhat slower pace than in the succeeding two years. Total spending increased at a 3.4 per cent annual rate from the fourth quarter last year to the second quarter this year, down from the 8.4 per cent rate from 1964 to 1966 . In contrast, spending by ultimate users of goods and services actually rose at a faster rate in early 1967 than in the preceding two years. Final sales rose at an 8.5 per cent annual rate of increase in the first half of 1967 , above the 7.9 per cent average rate from 1964 to 1966 . From 1960 to 1964 final sales grew at an average of 5.8 per cent a year. In real terms (i.e., adjusted for price changes), the rise was at a 6.4 per cent rate in the first half of 1967 , also slightly above the average rate for the preceding two years. The slowing in the growth of total outlays, despite the rise in final sales, resulted from businesses decreasing inventories or reducing the rate of increase.

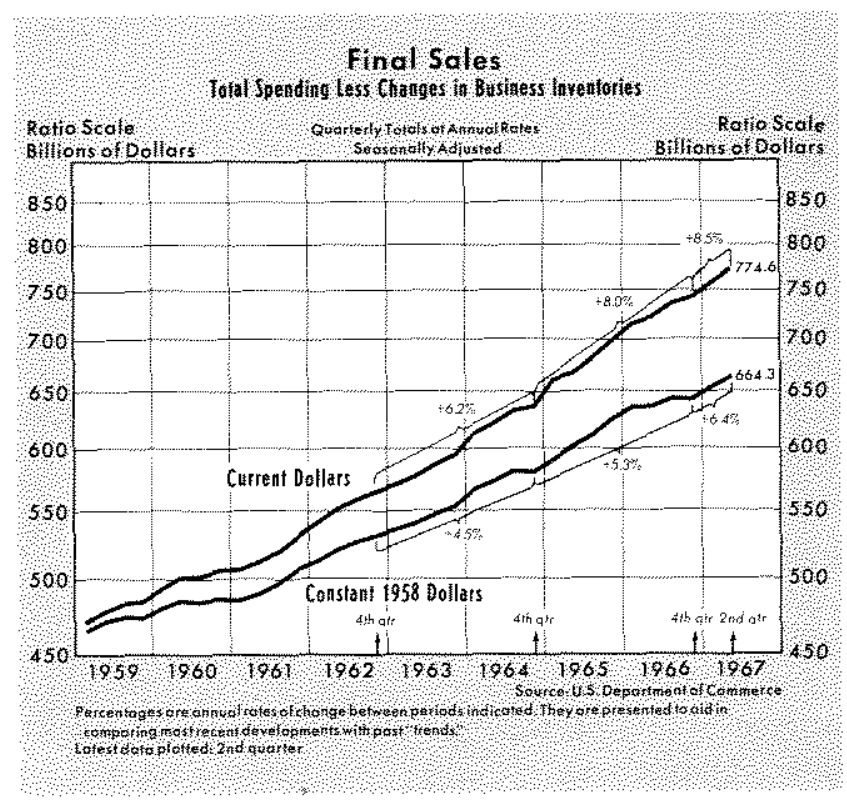




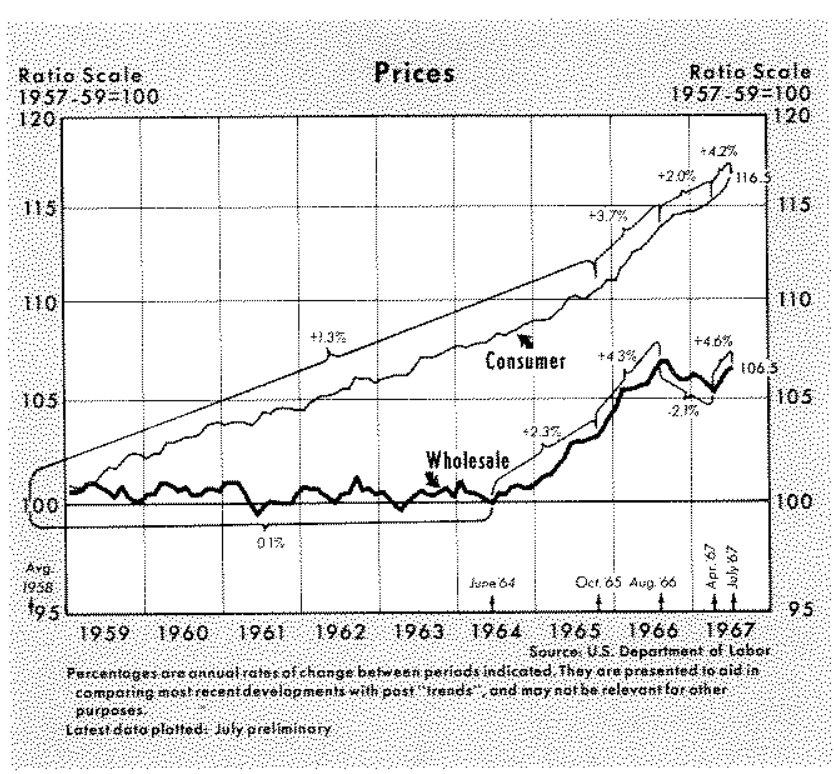

General price levels have risen markedly in recent months but as of July, did not reflect the pressure of total demand so much as the food supply situation. Consumer prices rose at a 4 per cent annual mate from April to July, well above the 2 per cent rate from August to April. For all items except food, consumer prices rose at a 3.1 per cent annual rate from April to July, compared with a 3.3 per cent rate from August to April. From 1958 to 1966 consumer prices rose at an average 1.5 per cent rate. Wholesale prices rose at a marked 5 per cent rate from April to July, after declining from August 1966 to April of this year. This upturn in prices was principally due to a sharp increase in prices of farm products and processed foods which declined in late 1966 and early 1967. Prices of finished industrial goods rose at a 1.7 per cent rate from April to June compared with a 1.3 per cent annual rate from October to April.

Despite signs of accelerating rates of economic activity, some evidences of the earlier slowdown remained in the early summer. Manufacturing, which accounts for about 30 per cent of total output, has been one of the weakest sectors. Industrial production declined during the first six months of this year before recovering half the decline during July and August. The decrease in industrial production during the first half of the year amounted to less than 2.5 per cent and may have been adversely affected by strikes.

The rate of industrial capacity utilization slipped to an average of 85 per cent in the second quarter, down from the 91 per cent a year earlier. It has remained near 85 per cent since the second quarter. This operating rate, however, compares with an 83.7 per cent average from 1962 through 1964 . Although the unemployment rate rose slightly in the second quarter, it

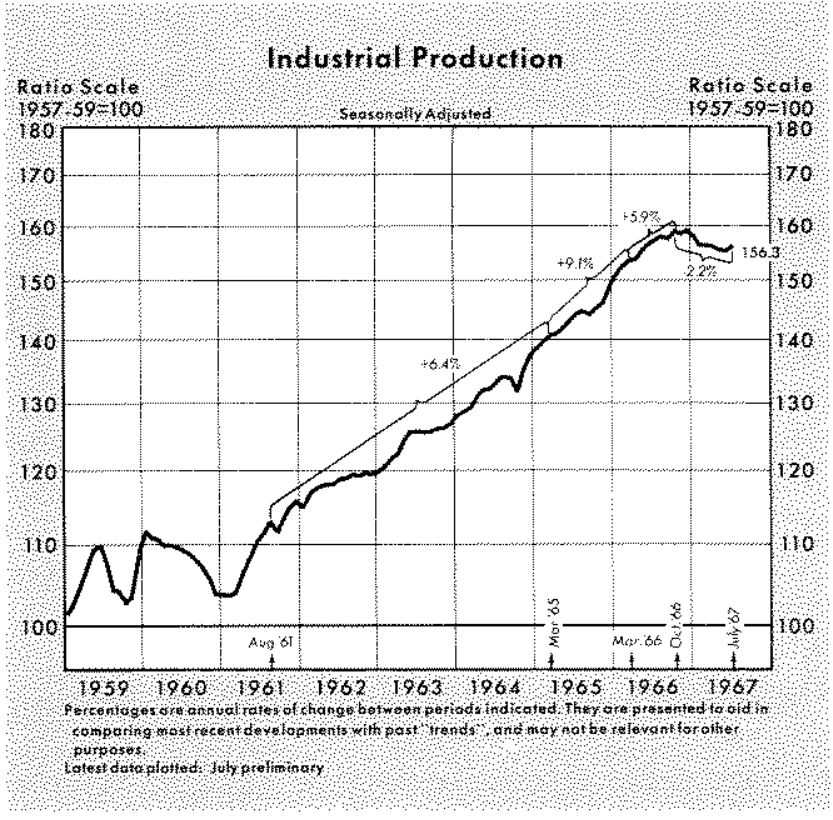

was below 4 per cent in July and August and well below the 5.5 per cent average rate from 1962 through 1964.

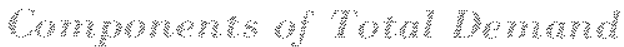

Some perspective on recent and potential developments is gained by analyzing various components of total demand. The first of these components consists of those categories of total spending which have grown at relatively stable rates. These stable components include consumer expenditures on nondurable goods and services, and expenditures of state and local governments.

A second component comprises those categories of total demand which have grown at widely varying rates, generally fluctuating in a cyclical pattern. These fluctuating components include consumer expenditures on durable goods, private fixed investment (residential and nonresidential structures, and producers' durable equipment), changes in business inventories, and net exports of goods and services.

Finally, Federal Government expenditures on goods and services are a separate category of total demand since they are, in part, subject to policy control. Usually they tend either to grow steadily or to move countercyclically. However, large items such as defense expenditures, which occur in spurts in response to external conditions, may cause total Government spending to move procyclically.

The stable components of total demand have maintained a steady aggregate rate of growth over the last five years. These components grew at an average annual rate of 7 per cent from the first quarter of 1963 
to the second quarter of 1967.

On the other hand, the fluctuating components of total demand grew at a very high 11 per cent annual rate from 1963 to 1965 , inclusive. Following this rapid expansion they have declined at a 4 per cent rate since the end of 1965 . These outlays typically rise rapidly in periods of economic expansion and decline in periods of contraction. The recent pause in the economy had some characteristics of an old-fashioned "business cycle trough," Downward adjustments of previously high levels of investment by consumers and businessmen acted as a brake on the economy in the classical manner. The sum of changes in the dollar values of the stable and fluctuating components was negative in the first quarter of 1967 and changed little in the second quarter.

The rapid rate of increase of Federal Government expenditures on goods and services helped to maintain total demand in early 1967. These expenditures showed little net change during 1963 and 1964, but, bolstered by the Vietnam situation and expanded welfare programs, Government outlays increased at a 12 per cent rate during 1965 , and have risen at a 19 per cent rate since then. The continuing buildup in the Federal Government sector during early 1967 offset a decline in the private sector, leaving total spending about un changed.

Given the likelihood of continued growth in the stable components, the key to acceleration in total demand is either a turnabout in the fluctuating components or an increasing rise in Federal expenditures. Either of these, and especially a combination of the two, could absorb any slack presently in the economy and might quickly set the stage for greater upward pressure on prices.

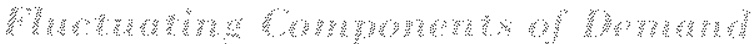

Analysis of the fluctuating components seems to indicate that an upturn may have begun sometime in the second quarter of 1967. Consumer purchases of durables rose at a 16 per cent rate from the first to the second quarter after declining in the two previous quarters. The rise reflected chiefly a sharp increase in automobile sales. Retail trade data for July and early August indicate further expansion in sales of consumers' durable goods. Consumers used the first quarter to restore their liquidity by reducing the growth of instalment debts and by adding to their savings balances. Credit for the purchase of automobiles and other consumer durable goods rose at only a 3.6 per cent annual rate from November to June after growing 10 per cent in the preceding year. These credit developments, together with the continued rise in personal

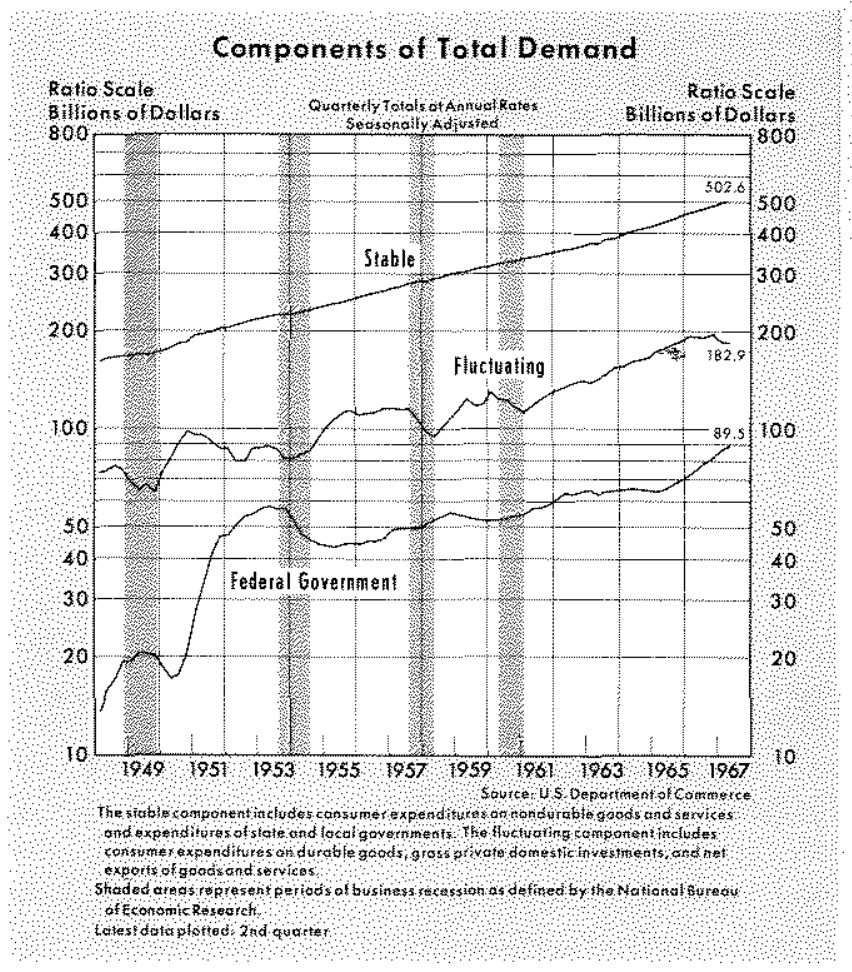

incomes, have now given consumers the means to increase their buying.

Nonfarm business inventories showed a nominal increase in the second quarter of 1967, after reaching a peak $\$ 19$ billion increase in the fourth quarter of 1966 . In June inventories of both manufacturing and trade firms declined. The inventory to sales ratio for both manufacturing and trade was 1.54 in July, down slightly from May, but still above the 1.48 ratio of a year ago. Wholesalers and retailers have apparently been more successful in bringing the inventory-sales ratio back to more normal levels. Manufacturing inventories of durables, more than of nondurables, seem to be high relative to sales. However, this may not inhibit further production of durables because of the low levels of auto inventories, defense needs, and the uncertainty concerning work stoppages in some dur-

Changes in Bustness Inventories

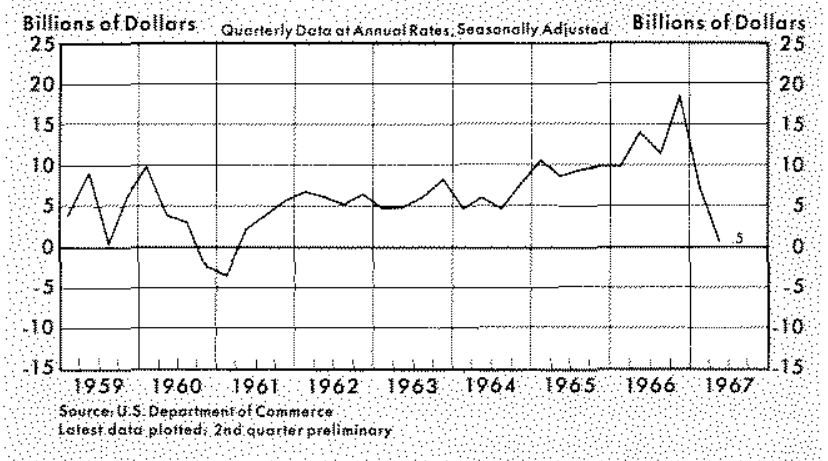


able goods industries. Also, expectations of further price advances in some areas may raise the level of desired inventories. New factory orders have been rising relative to shipments, resulting in a somewhat longer backlog of unfilled orders and thus help to adjust inventory levels without cutbacks in production. Although building of inventories may not become the strong addition to total demand in the near future that it was in late 1966, a return to pre-1966 levels would represent a sizable stimulus.

Investment in producers' durable equipment in the second quarter recovered almost to the level of fourth quarter 1966. Because of the uncertain effect of the investment tax credit restoration, the decline of corporate profits, and the lower rate of capacity utilization, there was a decline in business construction. This decline was enough to reduce total investment in the second quarter. Now that inventories are more nearly in balance, industrial production has shown signs of increasing, business profits are improving, and fixed investment by business may be expected to expand.

Residential construction has shown a modest increase during the first half of the year compared with the low fourth quarter of 1966 but remains well below the high levels of 1964 and 1965. Despite rising construction costs and some firming of interest rates in recent months, contract awards and housing starts point to some future strength in this area. Substantial amounts of funds have been flowing into savings and loan associations and mutual savings banks, but these intermediaries have used a large portion of these funds to reduce borrowings from the Federal Home Loan Board and to restore their reduced liquidity. Interest rates on mortgages have not fallen, apparently because some institutions which usually invest in mortgages have been attracted by the high rates offered on securities issued by businesses and Federal agencies.

Total private investment in the first half of the year dropped at an 18 per cent annual rate from the second half of 1966. Examination of the components suggests that strength began developing in the second quarter and a turnabout may have occurred. In view of the previous levels of operation and existing unused capacity, a moderate rise in the growth rate of total demand would be a healthy move toward more efficient utilization of resources. A return to the 1966 pace, however, would be unsustainable and would probably place excessive demands on the available supply of resources.

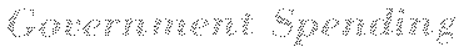

The fiscal operations of the Federal Government have had a stimulative effect on the economy since mid-

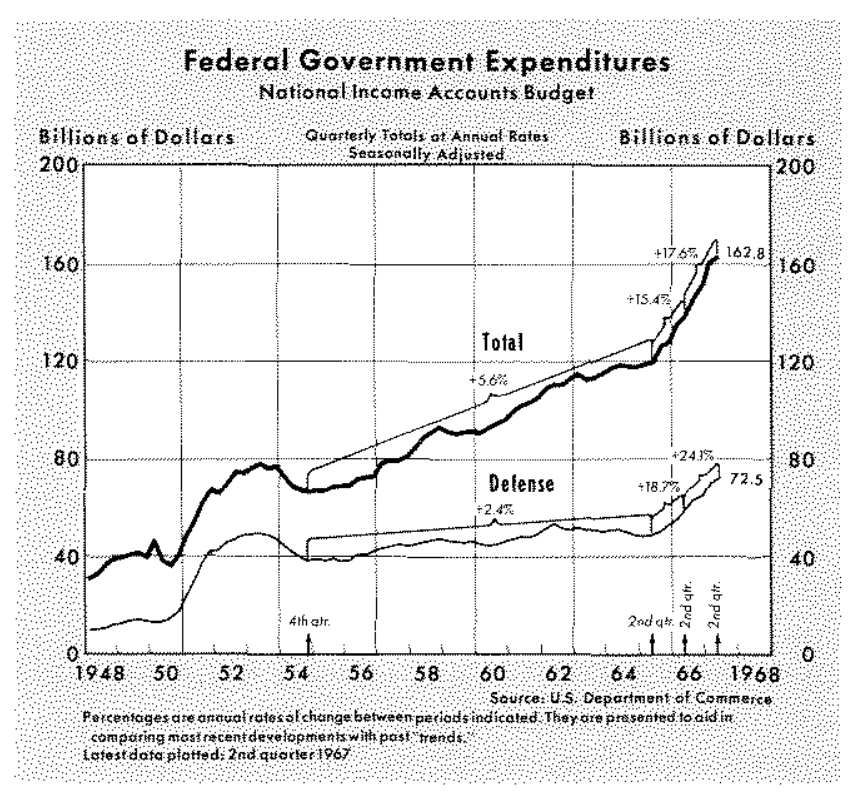

1965, primarily because of spending related to the Vietnam War. This stimulus is expected to continue over the foreseeable future, although it may be reduced if the proposed tax surcharge is passed.

Defense expenditures rose 24 per cent from mid1966 to mid-1967, compared with 19 per cent in the preceding twelve months. From mid-1963 to mid-1965, defense spending had been virtually unchanged.

The high-employment budget, a measure of the impact of fiscal actions, showed about an $\$ 8$ billion deficit in the year ending mid-1967, compared with a near balance in the corresponding period a year earlier. The high-employment budget, which adjusts the national income accounts budget for the effect of varying economic activity on tax receipts and on unemployment insurance disbursements, had shown an average

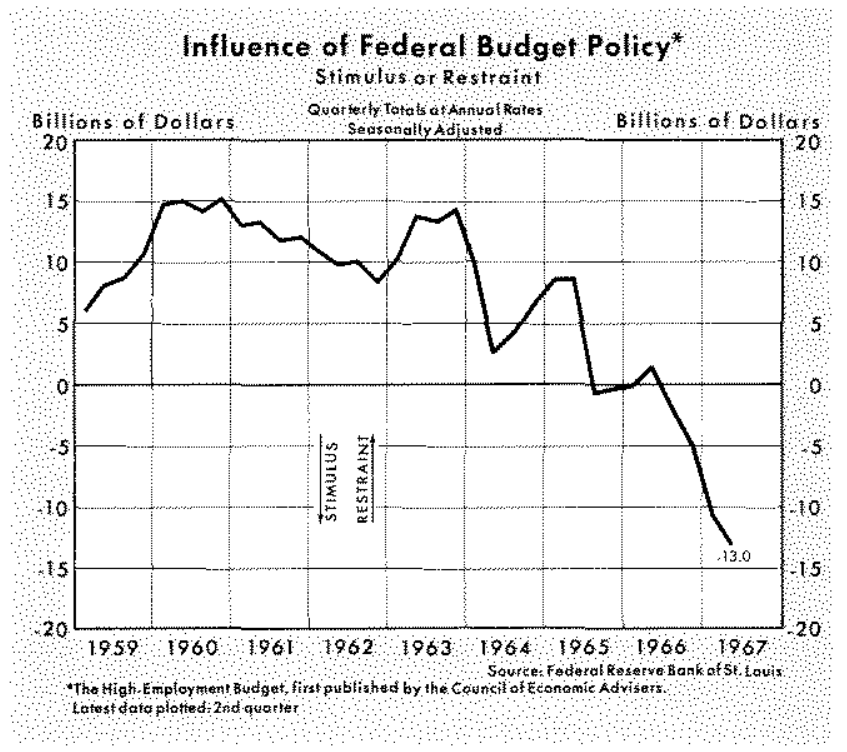


surplus of about $\$ 11$ billion from 1960 to mid-1965.

The proposed 10 per cent surcharge, when effective, would reduce the deficit in the high-employment budget by about a $\$ 10$ billion annual rate. The stimulus from budget actions would then be dampened, but assuming probable increases in spending, deficits of about $\$ 5$ billion in the high-employment budget might still be expected in early 1968 . This would be less expansionary than in the first half of 1967 , but about $\$ 13$ billion more stimulative than in 1963 through 1965 .

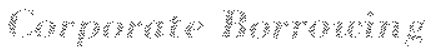

Corporations have been drawing on the capital market at a record rate this year, despite cutbacks in their investment expenditures. Some of these long-term funds apparently have replaced bank loans which had been used to finance last year's investment surge. Also, corporate earnings, which declined markedly in the first half of 1967, have generated fewer internal funds to satisfy the liquidity and capital formation needs of corporations. Over the last two years corporations have been required to pay taxes on a more current basis. The strong demands for funds by corporations as well as municipalities and the Federal Government have rem sulted in a rise in long-term interest rates despite some loss of industrial momentum and a climate of rapid monetary expansion.

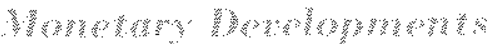

Monetary developments have been expansive since early this year. Total member bank reserves have grown at an annual rate of 7 per cent during the last six months, almost double the 4 per cent trend rate from 1960 to 1966 . Reserves available for private demand deposits (reserves other than those needed to support Government, interbank and time deposits) have increased at a 9 per cent rate from February to August, compared with a 2 per cent trend rate since 1960.

The money stock has risen at a 9 per cent rate over the past six months after changing little in the previous half year. By comparison, money grew at a 2.7 per cent rate from 1960 to 1964 and at a 4.2 per cent rate from 1964 to 1966.

Money stock plus time deposits in commercial banks (a broader concept of money) rose at a 13 per cent rate from February to August. This measure of money rose at a 5 per cent rate in the previous six months and at a 7.5 per cent rate in the 1960 to 1966 period.

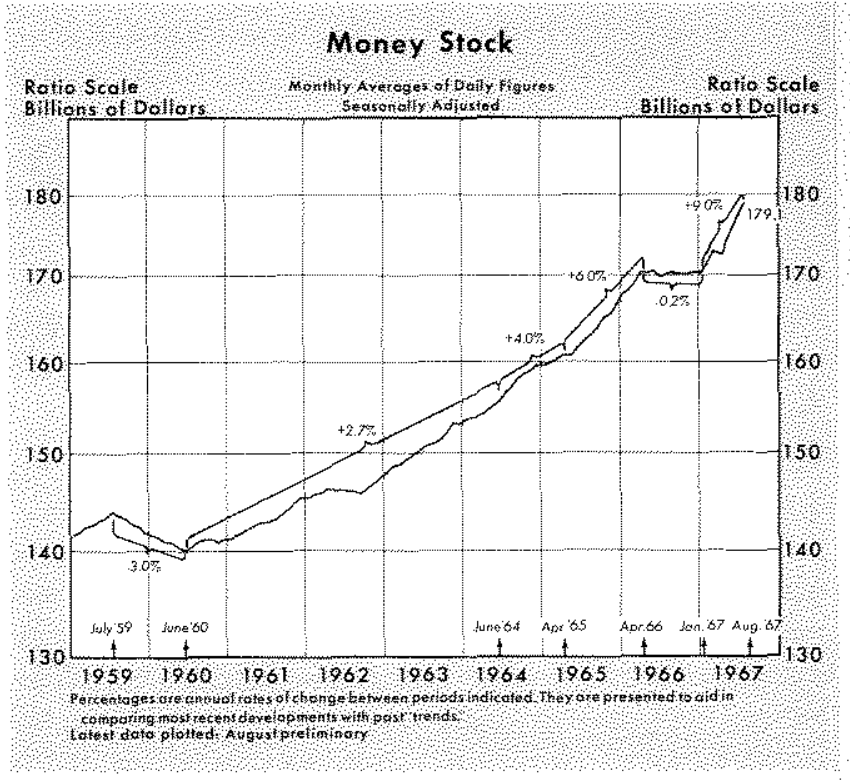

Commercial bank credit has grown at an estimated 13 per cent annual rate since January compared with growth of about 6 per cent in the preceding year. Commercial banks have increased their investments in Government, and state and municipal securities at a high 24 per cent annual rate since January after making little net change in investments last year. Commercial bank loans have grown at an 8 per cent annual rate in the first seven months of this year, about half the rate in the same months of 1966, and more than twice the 2.3 per cent annual rate during the last five months of 1966.

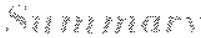

The economy has apparently skirted what might have become a recession. Mounting inflationary pressures have again become a current problem. Bank reserves, bank credit, money and savings accounts have all been rising rapidly, yet interest rates have increased in response to a vigorous demand for credit.

The extremely high level of Govermment spending, which maintained final demand at a high rate of increase earlier this year, continues to be expansionary. This spending must be financed. The full effects of the resulting stimulative deficit and the necessary financing effort may continue to act on the economy after the private sector is again accelerating. The proposed tax surcharge would help relieve the pressures on prices and interest rates, but questions remain as to whether this action alone would be sufficient to prevent inflation and even higher interest rates.

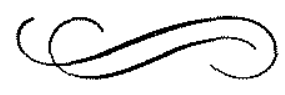

